of the agency's charter. The ensuing Comment discusses the theories of interpretation and the rules of construction which the World Court brought to bear on the solution of that question.

-The Editors

\title{
THE IMCO OPINION:* A STUDY IN TREATY INTERPRETATION
}

EXAMINATION of the principles of construction employed by the International Court of Justice in its recent advisory opinion, Constiuttion of the Maritime Safety Committee of the Inter-Governmental Maritime Consultative Organization, ${ }^{1}$ illustrates the Court's theory of treaty interpretation. Those principles are: (a) Words must be given their natural and ordinary meaning in context. (b) Treaties, and particular articles thereof, must be interpreted as a whole. (c) The intended meaning may be revealed by preparatory documents. (d) Particular words may be viewed in the light of the apparent purpose of the treaty. (e) The intended meaning may be revealed by subsequent practice of the parties. (f) The meaning of words according to usage contemporaneous with the inception of the treaty must be considered.

\section{Factual Background}

The Inter-Governmental Maritime Consultative Organization (IMCO) is a specialized United Nations agency primarily "concerned with maritime safety and efficiency of navigation." Article 28(a) of its convention provides: ${ }^{3}$

The Maritime Safety Committee shall consist of fourteen Members elected by the Assembly from the Members, governments of those nations having an important interest in maritime safety, of which not less than eight shall be the largest ship-owning nations, and the remainder shall be elected so as to ensure adequate representation of Members, governments of other nations with an important interest in maritime safety, such as nations interested in the supply of large numbers of crews or in the carriage of large numbers of berthed and unberthed passengers, and of major geographical areas.

* Constitution of the Maritime Safety Committee of the Inter-Governmental Maritime Consultative Organization, $[1960]$ I.C.J. Rep. 150 (Advisory Opinion of June $8,1960)$.

\footnotetext{
${ }^{1}$ [1960] I.C.J. Rep. 150 (Advisory Opinion of June 8, 1960).

${ }^{9} I d$. at 153 .

sId. at 154 .
} 
In 1959, a dispute arose over the election of the "eight largest shipowning nations." Although Liberia and Panama were among the first eight countries listed on the registered tonnage table of Lloyd's Register of Shipping Statistical Tables x958, both failed of election. ${ }^{5}$ On motion of those two countries, IMCO requested the World Court to give its opinion ${ }^{6}$ on the question, "Is the Maritime Safety Committee ... constituted in accordance with the Convention for the Establishment of the Organization?" The Court decided that the committee was not properly constituted. ${ }^{8}$

\section{Principles of Construction}

\section{A. Natural and Ordinary Meaning}

The nations asserting the validity of the election ${ }^{9}$ contended that the word "elected" connoted choice and that each member of the assembly

\footnotetext{
'The members displayed a wide divergence of views concerning the requirements of article 28(a). Liberia and Panama believed that the assembly had no choice but to elect the eight largest shipowning nations as listed in the gross registered tonnage tables of Lloyd's Register of Shipping. The United Kingdom, however, contended that the assembly had to choose eight countries which, "on the one hand, had an important interest in maritime safety and, on the other hand, were the largest shipowning nations...." Id. at 156 . Neither Liberia nor Panama, it was asserted, was then in a position to make a contribution to the work of the committee because each lacked knowledge and experience in the area of maritime safety. Moreover, it was urged, relative importance as shipowning nations should be dependent upon the tonnage actually belonging to a nation rather than that registered under its flag.

"The election procedure which had been proposed by the United Kingdom required that a separate vote be taken for each place on the committee and that the first eight receiving a majority be elected. The vote was taken in the order that the countries appeared in Lloyd's Register. Id. at 155.

- Article 65 of the Statute of the Court authorizes the rendering of an advisory opinion. The IMCO convention "provides in Article 56 that questions of law may be referred to the International Court of Justice for advisory opinions." Id. at $15 \mathrm{x}$.

${ }^{7} I d$. at $15 \mathrm{I}$. The Court noted that the question submitted to it, though cast in a general form, "is directed to a particular case, and may be formulated in the following manner: has the Assembly, in not electing Liberia and Panama to the Maritime Safety Committee, exercised its electoral power in a manner in accordance with the provisions of Article $28(a) \ldots$..." Id. at $152-53$.

${ }^{8}$ The Judges stood 9 votes to 5. The Court consisted of: President Klaestad; Vice President Zafrulla Khan; Judges Basdevant, Hackworth, Winiarski, Badawi, Armand-Ugon, Kojevnikov, Moreno Quintana, Córdova, Wellington Koo, Spiropoulos, Sir Percy Spender and Alfaro. President Klaestad, $i d$. at $173-76$, and Judge Moreno Quintana, id. at $177-78$, appended dissenting opinions.

${ }^{\circ}$ The United Kingdom and the Netherlands defended the validity of the election in the oral arguments before the Court. Id. at $156-57$. On the other hand, the United States, in addition to Liberia and Panama, maintained that the election was invalid.
} 
was therefore free to vote according to its own appraisal of the nominees. President Klaestad, in a dissenting opinion, agreed, ${ }^{10}$ but the majority rejected that interpretation." ${ }^{11}$ The meaning of "elected,"12 the Court stated, "cannot be determined in isolation by recourse to its usual or common meaning and attaching that meaning to the word where used in the Article. The word obtains its meaning from the context in which it is used."13 The Court noted that eight committee members were to be "the largest ship-owning nations," which is a "definite and pre-established criterion." The remaining six seats were to go to other nations "having an important interest in maritime safety," which is a "matter of choice." Because the same word, "elected," was used to refer to the second category as well as to the first, the Court concluded that its meaning must differ with the context to which it referred. ${ }^{14}$

\section{B. Reading the Treaty as a Whole}

Article 28(a) requires that committee members have an "important interest in maritime safety." Viewed "in the context of the whole provision," the Court held that possession of that qualification by the eight largest shipowning nations must be implied from "the structure of the Article."15

The phrase, "in the context of the whole provision," suggests the principle that treaties, and particular articles thereof, are to be read as a whole. This principle is in one sense an expansion of the "context" within which the first principle requires particular words to be given their ordinary and natural meaning. However, the particular role of this second principle is made evident in the IMCO Opinion.

Id. at 157. Italy and Norway also presented oral arguments but their positions are not revealed in the advisory opinion. Written statements were submitted by Belgium, France, the Republic of China, Switzerland, Denmark, and India. Id. at 152 .

${ }^{10} 1 d$. at $173-74$.

${ }^{11}$ The Court pointed out that the rejected interpretation "assumes a meaning to be accorded to the word 'elected' and then applies that meaning to Article $28(a)$ and interprets its provisions accordingly." Id. at ${ }_{5} 8$.

${ }^{13}$ The first word "elected" appearing in article $28(a)$.

${ }^{13}$ Ibid.

${ }^{14} I d$. at 159 .

${ }^{26} I d$. at 160 . The Court also noted that, with respect to the eight, the requirement of "having an important interest in maritime safety" is left undefined. As to the "other nations," however, that phrase is followed by the words "such as" and a list of examples as to what constitutes the required "important interest." "The use of the words 'other nations' and 'such as' in their context confirms this interpretation." Ibia. 
Article 28(a) specifies two conditions of membership on the Maritime Safety Committee. All members are to have an "important interest in maritime safety" and eight are to be "the largest shipowning nations." Because the latter qualification did not expressly include the former, the Court had to decide whether the assembly was free to reject one of the first eight nations on Lloyd's List on the theory that it lacked an "important interest in maritime safety." From a reading of the provision as a whole, the Court concluded that the "underlying principle"16 of article 28(a) is to secure control of the committee to the eight "largest ship-owning nations." That principle compelled the conclusion that any nation which is one of the "largest ship-owning nations" impliedly possessed the requisite interest. The Court was not concerned with the particular meaning of either phrasewhich could have been discovered by using the natural and ordinary meaning principle. Rather, it was concerned with discovering the relation between the two phrases-which necessitated reading article $28(a)$ as a whole.

\section{Meaning Revealed by Preparatory Documents}

The Court sought to throw further light on the "underlying principle" of article $28(\mathrm{a})$ by examining preliminary drafts of the treaty and the records of the parties' debates prior to its adoption. ${ }^{17}$

The first draft of the article provided for a committee of twelve members to be selected from

those nations having an important interest in maritime safety and owning substantial amounts of merchant shipping, of which no less than nine shall be the largest ship-owning nations and the remainder shall be selected so as to ensure representation for the major geographical areas. ${ }^{18}$

Several countries objected to the exclusion of all but shipowning nations. In particular, the Indian delegate pointed out that "other countries 'who did not actually own or have a large number of merchant vessels' had also important interests in maritime safety."

\footnotetext{
${ }^{10} \mathrm{Ibid}$.

${ }^{17}$ The process is similar to that employed by national courts when they resort to legislative history as a guide to the interpretation of statutes.

${ }^{18} I d$. at $I 6 \mathrm{I}$.

${ }^{10} \mathrm{Id}$. at 163 . The nations with other important interests were asserted to be those "interested in the supply of large numbers of crews or in the carriage of large numbers . . of passengers." Id. at 164. An alternative draft was prepared which eliminated the words "having [which had been earlier changed from "owning," $i d$. at I62] substantial amounts of inerchant shipping" and reduced the number of largest
} 
though the dissatisfied nations were successful in eliminating ship ownership as a qualification for membership on the committee and in reducing the majority of the largest shipowners, the several drafts and debates clearly indicated that "the intention that it should be obligatory upon the Assembly to appoint to the Committee a predominating number of the largest ship-owning nations remained constant . . . .20

\section{Apparent Purpose of the Treaty}

The fourth principle of construction employed in the IMCO Opinion has been called the principle of effectiveness. ${ }^{21}$ That is, words and phrases must be construed in the way that gives greatest effect to the apparent purpose of the treaty. The principle is typically applied by assuring that reason and meaning are given to every part of the text.

Having concluded that the eight largest shipowning nations also possessed the "important interest in maritime safety" required for committee membership, the Court further observed that any other conclusion would "render superfluous the greater part of Article 28(a) . . ."22 President Klaestad, however, used the principle of effectiveness to reach the opposite result. He felt that the Court's interpretation rendered superfluous the first condition, relating to the interest in maritime safety, whereas his interpretation would "not render superfluous the second condition relating to 'the largest ship-owning nations' or any other part of that Article."23

In concluding the $O$ pinion, the Court used the effectiveness principle to justify its position. It observed that the committee's function is

shipowning nations to seven. The final draft followed the language of the alternative draft but increased the total membership to fourteen of which only eight were to be the largest shipowning nations.

${ }^{20} 1 d$. at 164 . The Court used preparatory documents in a negative fashion when it rejected the argument that the word "elected" was intended to give the assembly some discretion in choosing the largest shipowning "nations. "Selected" and not "elected" had appeared in all the drafts including the "final" one which was accepted, however, subject to "drafting changes." The change was made by a drafting committee after the final conference and before the convention was submitted to the members for adoption. Of course, there was no debate on the point. The Court said, "thère was apparently no explanation for, or any discussion on, the alteration. It was a mere drafting change. If the word 'elected' had the special significance sought to be attached to it, it seems unlikely that the word would have found its way into the Article in this manner." $r d$. at 165 .

${ }^{22}$ It is also referred to by the phrase ut res magis valeat quan periat-that the thing may have effect than be destroyed.

${ }^{39} I d$. at 160 .

${ }^{23} I d$. at $\times 75$. 
purely consultative and that the cooperation of those states with jurisdiction over the largest portion of the world's maritime tonnage is therefore essential to the success of the committee's proposals for maritime regulation. The Court felt that its "interpretation ... [of] Article $28(a)$ is consistent with the general purpose of the Convention and the special functions of the Maritime Safety Committee."24

Having resolved that the assembly was obligated to elect the eight largest shipowning nations, the Court observed that the only practical means of determining which nations fell within that category was on the basis of their tonnage. Accordingly, the meaning of "ship-owning nations" could refer only to "tonnage beneficially owned by the nationals of a State or ... to the registered tonnage of a flag State regardless of its private or State ownership."25 By utilizing two other principles of interpretation, the Court concluded that the reference must be to registered tonnage.

\section{E. Subsequent Practice}

The Court found that in carrying out three other provisions of the convention, the parties had consistently used registered tonnage as a guide. Article ${ }^{7} 7$ (c) requires the assembly to elect two members to the IMCO council from nations "having a substantial interest in providing shipping services." Without objection, the registered tonnage of the nominees was the standard employed. Similarly, the assembly had resolved that the organization's expenses were to be apportioned among the members according to their registered tonnage. Finally, article 60 of the convention provides that it would "enter into force ... . when 2 I States [,] of which seven shall each have a total tonnage of not less than $\mathrm{I}, 000,000$ gross tons of shipping, have become parties . . . .266

\footnotetext{
"Id. at I70. Having concluded that the eight largest shipowning nations must be elected to the committee, the Court next had to decide what was meant by the "largest ship-owning nations." The United Kingdom argued that smce those words had "no apparent or clear-cut meaning" but were intended merely to guide the assembly, that body could look at "the realities of the situation" and determine for itself which nations fell within the guide "in a real and substantial sense." Id. at 166 . Again the Court turned to the effectiveness principle. To give effect to the mandatory words, "not less than eight shall be the largest ship-owning nations," the Court concluded that the United Kingdom's position had to be rejected.

${ }^{25} I d$. at 167 . The Court rejected without explanation the notion that the ships had to be owned by the state itself.

${ }^{20}$ Ibid. The Court further observed that, in the English text of the treaty, nations were described in article $28(a)$ as "owning" ships, but that in article 60 the reference was to states which "have" a prescribed total tonnage. On the other hand, the French
} 
The tonnage for that purpose had been determined by use of the Lloyd's Register tables.

These practices, adopted by the parties themselves, persuaded the Court that it was "unlikely"27 that any standard other than registered tonnage was intended to be applied for purposes of article 28(a) elections.

\section{F. Contemporaneous Usage}

In concluding that "ship-owning nations" referred to registered tonnage, the Court also turned to the principle of contemporaneity. It sought out the meaning of similar terms in four treaties in force when the IMCO convention was under consideration. In each case, it found that a ship was "commonly ... considered" to be owned by a state if it was registered under that country's flag. On the assumption that "Article 28(a) was drawn up by maritime experts who might reasonably be expected to have been acquainted with previous and existing conventions concerned with shipping and dealing with safety at sea and allied subjects,"20 the Court affirmed its conclusion that it was "unlikely"30 that the draftsmen would have intended to refer to any standard other than registered tonnage without making such an intent clear. ${ }^{31}$

\section{Theories of INTERPRETation}

The primary objective of treaty interpretation ${ }^{32}$ is to give effect to the intentions of the parties. There are, however, three principal

and Spanish texts used the same verb, "to own" (or "to possess") in both articles. The Court found that article 60 indisputably referred to registered tonnage irrespective of whether the verb employed was "to own" (as in the French and Spanish) or "to have" (as in the English). It therefore concluded that the use of the English word "owning" in article $28(\mathrm{a})$, rather than "have" as in article 60, should not be given the special significance suggested by interpreting "ship-owning nations" as meaning "state-ownership." Id. at $167-68$.

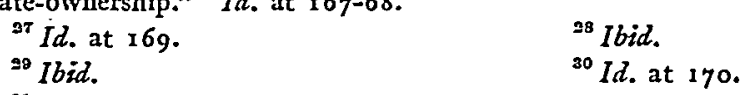

${ }^{31}$ The Court further observed that " $i$ it, indeed, not without significance that about the time the draft Article was finally settled, Lloyd's Register for $194^{8}$ listed as belonging to the various countries of the world the vessels registered in those coun'tries and that under the heading 'Countries where owned' there were given the 'number and gross tonnage of vessels which are the same as those registered under the flag of each nation indicated." Ibid.

"For a comparison of "strict" and "liberal" treaty interpretation, see Lauterpacht, Restrictive Interpretation and the Principle of Effectiveness in the Interpretation of Treaties, 26 BRIT. YB. INT'L L. $48-85$ ( 1949 ). 
schools-intentionists, textualists, and teleologists-which differ on the method of achieving that objective. ${ }^{33}$ Intentionists declare that the only legitimate object of interpretation is to effectuate the intent of the parties. Their first objective, therefore, is to ascertain that intent from the declarations and actions of the parties. The teleologists' principal concern is with the existing purpose of the treaty, which may have become quite independent of its framers' intentions. Teleologists, therefore, search for the general purport of the text, the factors that occasioned its inception, and the circumstances surrounding its continued operation in the international sphere. Textualists maintain that the meaning of the text must be established according to the ordinary and natural significance of its words. Thus, they turn first to an analysis of the text. The several principles of interpretation applied in the IMCO Opinion have characteristics suggesting that all three of these approaches have influenced the Court's own theory of interpretation.

\section{A. Intentionist Principles}

The Court's examination of preparatory documents ${ }^{34}$ and of the subsequent practice of the parties ${ }^{35}$ was occasioned by its concern with the problem of intention. Statements of the parties who participated in preadoption deliberations may be direct evidence of the meaning which they intended particular words to convey. ${ }^{36}$ Similarly, the Court regards the parties' postadoption practices in relation to a treaty as having "considerable probative value."37

${ }^{33}$ See generally, Morse, Schools of Approach to the Interpretation of Treaties, 9 Catholic U.L. REv. 36 (1960); Fitzmaurice, The Law and Procedure of the International Court of Justice: Treaty Interpretations and Certain Other Treaty Points, 28 BRIT. YB. INT'L L. I-2 (195I).

${ }^{84}$ It will be recalled that the Court resorted to an extensive examination of preliminary drafts and the debates thereon to demonstrate that the parties had consistently envisioned the predominance of the major shipowning nations on the committee. See note I7 supra and accompanying text.

${ }^{85}$ The Court reached the conclusion that ship ownership was to be measured by registered tonnage through the application of this principle. See note 27 supra and accompanying text.

${ }^{30}$ "[I] $]_{\mathrm{t}}$ is well known that ... the value of travaux préparatoires is based, for purposes of interpretation, on the voluntas legislatoris ...." Competence of the General Assembly for the Admission of a State to the United Nations, [1950] I.C.J. Rep. 4, 23 (Advisory Opinion of March 3, I950) (Judge Azevedo dissenting).

s7 International Status of South-West Africa, [1950] I.C.J. Rep. 128, 135-36 (Advisory Opinion of July II, 1950). The Court has considered subsequent practice in: Case Concerning Right of Nationals of the United States of America in Morocco (France v. United States of America), [1952] I.C.J. Rep. 176, 210-i I (Judgment of August 27, 1952); Anglo-Iranian Oil Co. Case (Preliminary Objection) (United 
The relative weight to be assigned to these two types of evidence is open to question. On the one hand, it has been suggested ${ }^{38}$ that preparatory documents may be generally confusing because they usually contain material which will support each of the contentions on the point in issue; they may be misleading because important decisions made in private discussions do not appear in official records; they may not even achieve their purpose of discovering the parties' intent because disputes over meaning usually result from a lack of common intention in the first place. Where, as in the IMCO Opinion, the Court is dealing with a multilateral treaty, an additional complication militates against the use of preparatory work. Such treaties, and especially those which establish an international organization, are frequently open to unilateral accession by nations which did not participate in the debates preceding adoption. The acceding party's intentions may be quite different from those of the originating nations. Moreover, continued operation of an organization such as IMCO will probably result in interpretive practices that supersede the original intentions of the first participants. ${ }^{30}$ Such superseding interpretations are subsumed within the category of subsequent practice, which is increasingly regarded as a more reliable indicia of intent than preparatory work. As a recently appointed Judge of the World Court has said: "[I]n the course of preparatory work the parties merely state what their intentions are: in their practice subsequent to the conclusion of the treaty they act upon them."10

The Court's acceptance of the latter viewpoint is reflected in its restricted use of preparatory documents. In I952 it said, "In any case where, as here, the text to be interpreted is clear, there is no occasion to resort to preparatory work."34 In the same year, however, it modi-

Kingdom v. Iran), [1952] I.C.J. Rep. 93, 107 (Judgment of July 22, 1952); Competence of the General Assembly for the Admission of a State to the United Nations, [Y950] I.C.J. Rep. 4, 9 (Advisory Opinion of March 3, 1950); The Corfu Channel Case (Merits) (United Kingdom v. Albania), [1949] I.C.J. Rep. 4, 25 (Judgment of April 9, 1949). See also The Asylum Case (Merits) (Colombia/Peru), [1950] I.C.J. Rep. 266, 323-24 (Judgment of November 20, 1950) (Judge Read dissenting).

${ }^{3 a}$ Fitzmaurice, supra note 34 at $15-17$.

39 "A treaty or a text that has once been established acquires a life of its own." Competence of the General Assembly for the Admission of a State to the United Nations, [1950] I.C.J. Rep. 4, IS (Advisory Opinion of March 3, 1950) (disserit, Judge Azevedo expounding the teleologist approach).

. ${ }^{30}$ Fitzmaurice, The Law and Procedure of the International Court of Justice 2951-4: Treaty Interpretation and Other Treaty Points, 33 BRIT. YB. INT'L L. 203, 223 (1957). Sir Gerald Fitzmaurice was elected in 1960. He uses the term "preparatory work" which is the literal translation of the French "travaux "préparatoires."

- ${ }_{11}$ The Ambatielos Case (Preliminary Objection) (Greece v. United Kingdom), 
fied that view by referring to preparatory documents to confirm a conclusion reached by the application of another principle of interpretatation. ${ }^{42}$. In the IMCO Opinion, the Court examined drafts and debates for the latter purpose. ${ }^{43}$ While the Court has limited its resort to preparatory documents to occasions when they afford conformation of a particular interpretation ${ }^{44}$ or when the text is ambiguous, ${ }^{45}$ the evidence afforded by subsequent practice has been regarded as decisive of the matter in dispute. ${ }^{46}$ Indeed, in IMCO, the Court placed its principal reliance on the subsequent practice of the parties to resolve a question of crucial importance ${ }^{47}$ for which the text of the treaty failed to provide any suggestion of an answer. ${ }^{48}$

[1952] I.C.J. Rep. 28, 45 (Judgment of July 1, 1952). Accord, Competence of the General Assembly for the Admission of a State to the United Nations, [1950] I.C.J. Rep. 4, 8 (Advisory Opinion of March 3, 1950); Conditions of Admission of a State to Membership in the United Nations, [1948] I.C.J. Rep. 57, 63 (Advisory Opinion of May 28, 1948). In the latter opinion, the Court observed that the rule of nonrecourse to preparatory documents where the text is clear was the "consistent practice" of the Permanent Court of International Justice. Ibid.

Since The Ambatielos Case, the Court apparently has not found any occasion to use preparatory documents to clear up an ambiguity in the text. Two individual Judges have indicated that it may be so used, however. The Minquiers and Ecrehos Case (France/United Kingdom), [1953] I.C.J. Rep. 47, 87 (Judgment of November 17, 1953) (separate opinion of Judge Carneiro); Anglo-Iranian Oil Co. Case (Preliminary Objection) (United Kingdom v. Iran), [1952] I.C.J. Rep. 93, 117-18 (Judgment of July 22, 1952) (separate opinion of Judge McNair).

${ }^{42}$ Case Concerning Right of Nationals of the United States of America in Morocco (France v. United States of America), [1952] I.C.J. Rep. 176, 207-1i (Judgment of August 27, 1952). It should be noted that the jointly dissenting Judges in that case used the same approach to reach a different result. Id. at 229-33. The Court itself declared that "not much guidance is obtainable from these sources." Id. at 209 .

${ }^{43}$ See note 17 supra and accompanying text.

"See Fitzmaurice, supra note $4^{1}$ at $2 \times 8-19$ for the suggestion that the Court will resort to preparatory documents in two other circumstances where the text is unambiguous.

${ }^{25}$ As to "the nature of an ambiguity," see $i d$. at 216.

"Anglo-Iranian Oil Co. Case (Preliminary Objection) (United Kingdom v. Iran), [1952] I.C.J. Rep. 93, 107 (Judgment of July 22, 1952). See Case Concerning Right of Nationals of the United States of America in Morocco (France v. United States of America), [1952] I.C.J. Rep. 176, 231 (Judgment of August 27, 1952) (dissent). But see, International Status of South-West Africa, [1950] I.C.J. Rep. 128, 135-36 (Advisory Opinion of July x 1,1950 ).

${ }^{47}$ The question concerned the standard by which a nation's ship ownership should be measured. The Court found that the parties had consistently used flag registration as a guide. See note 27 supra and accompanying text.

${ }^{48}$ The Court turned first to subsequent practice. It then considered that the principle 
Although the relative weight to be assigned to preparatory documents and subsequent practice may be in doubt, the effect of both types of evidence is to throw light on the expressed intent of the parties. Therefore, to the extent that the Court relies on those principles, ${ }^{40}$ it has borrowed from the intentionist approach.

\section{B. Teleologist Principle}

Regarding the intent of the parties as the sole, legitimate object of interpretation ${ }^{50}$ is a viewpoint derived from familiar principles of contract law. So long as most treaties were bilateral or were confined to at most a few parties having a readily discernible common aim, a contractual analysis was generally acceptable. With the advent of the multilateral, multipurpose treaty and the international organization, however, the relevance of intent to the problem of interpretation began to be questioned. ${ }^{51}$ The teleologists, leaders in this attack, have not been without representation on the World Court. Judge Alvarez, dissenting ${ }^{52}$ in the second Admissions Case, said," "A treaty or a text that has once been established acquires a life of its own. Consequently, in interpreting it we must have regard to the exigencies of contemporary life, rather than to the intentions of those who framed it." Fearing, perhaps, that the Court might become involved in the legislative process of expanding, supplementing, or correcting texts, the majority of the Court has made only limited use of the teleological method. "It is the duty of the Court to interpret the Treaties, not to revise them." ${ }^{354}$

The Court has, however, turned to the apparent purpose or object of a treaty as a guide to interpretation. On several occasions ${ }^{55}$ it has

of contemporaneity led to the same result. See note 29 supra and accompanying text. It may not be said therefore that subsequent practice alone provided the answer to the question left open by the text.

${ }^{49}$ But Fitzmaurice, supra note 41 at 210 , declares that subsequent practice. has "opened the door to a predominantly teleological element of interpretation ....".

so "It is the intention of the authors of the legal rule in question-whether it be a contract, a treaty, or a statute-which is the starting-point and the goal of all interpretation." Lauterpacht, supra note 32 at 83 .

${ }^{51}$ Fitzmaurice, supra note 34 at 3-4.

${ }^{5}$ Fitzmaurice finds that while individual Judges have been teleologists, the majority of the Court adopts the textual approach. $I d$. at 7-8.

${ }^{53}$ Competence of the General Assembly for the Admission of a State to the United Nations, [1950] I.C.J. Rep. 4, 18 (Advisory Opinion of March 3, 1950).

ss Interpretation of Peace Treaties with Bulgaria, Hungary and Romania (Second Phase), [1950] I.C.J. Rep. 221, 229 (Advisory Opinion of July 18, 1950).

${ }^{55}$ The Ambatielos Case (Preliminary Objection) (Greece v. United Kingdom), 
sought to ensure that the maximum effect is given to every part of a treaty by viewing each provision in the light of the treaty's purpose..$^{50}$ As in the IMCO Opinion, ${ }^{57}$ the principle of effectiveness has typically been employed to avoid holding that a particular provision is superfluous and without effect. ${ }^{58}$ Nevertheless, the principle of effectiveness clearly occupies a position subordinate to the textual approach in the eyes of the Court. ${ }^{59}$ "The principle of interpretation . . . often referred to as the rule of effectiveness, cannot justify the Court in attributing to the provisions ... a meaning which ... would be contrary to their letter and spirit."

\section{Textualist Principles}

In the Iranian Oil Case, the Court expressed its primary concern for the "letter and spirit" of a treaty in this way: "This Declaration must be interpreted as it stands, having regard to the words actually used."'Th Tirst principle of the textual approach is that words are to be given their natural and ordinary meaning. ${ }^{62}$ It was to this prin-

[1952] I.C.J. Rep. 28, 45 (Judgment of July 1, 1952); Reparations for Injuries Suffered in the Service of the United Nations, [r949] I.C.J. Rep. 174, r78-79 (Advisory Opinion of April II, 1949). Accord, Acquisition of Polish Nationality, P.C.I.J., ser. B, No. 7 , at 17 (1923).

5o That "interpretation is to be favored which will make the instrument effective to serve its purpose." Hudson, The Permanent Court of International Justice rg20-1942, 65 I (1943).

${ }^{67}$ See note 21 supra and accompanying text.

${ }^{38}$ Anglo-Iranian Oil Co. Case (Preliminary Objection) (United Kingdom v. Iran), [1952] I.C.J. Rep. 93, ro5 (Judgment of July 22, 1952); The Corfu Channel Case (Merits) (United Kingdom v. Albania), [1949] I.C.J. Rep. 4, 24 (Judgment of April 9, 1949).

${ }^{50}$ Professor Lauterpacht, later a Judge of the World Court, concludes however that the International Court of Justice and its predecessor have "consistently acted upon the principle of effectiveness as the governing canon of interpretation." Supra note 33 at 68 .

${ }^{\circ 0}$ Interpretation of Peace Treaties with Bulgaria, Hungary and Romania (Second Phase), [1950] I.C.J. Rep. 22 I, 229 (Advisory Opinion of July 18, 1950).

${ }^{01}$ Anglo-Iranian Oil Co. Case (Preliminary Objection) (United Kingdom v. Iran), [1952] I.C.J. Rep. 93, I05 (Judgment of July 22, 1952). Accord, Case Concerning Right of Nationals of the United States of America in Morocco (France v. United States of America), [1952] 1.C.J. Rep. 176, 195-99 (Judgment of August 27, 1952).

"2 The Asylum Case (Merits) (Colombia/Peru), [1950] I.C.J. Rep. 266, 279 (Judgment of November 20, 1950); Interpretation of Peace Treaties with Bulgaria; Hungary and Romania (Second Phase), [1950] I.C.J. Rep. 22r, 227 (Advisory Opinion of July I 8, 1950); The Ambatielos Case (Merits: Obligation to Arbitrate) (Greece v. United Kingdom), [1953] I.C.J. Rep. ro, 30 (Judgment of May r9, I953) (dissent). 
ciple that the Court first turned in $I M C O .^{.3}$

It should be noted that when the Court applies the principle of natural and ordinary meaning, it will not confine itself to a narrow, literal reading. ${ }^{64}$ The Court cannot "base itself on a purely grammatical interpretation of the text. It must seek the interpretation which is in harmony with a natural and reasonable way of reading the text .... ${ }^{m 5}$ In short, words are to be given their natural and ordinary meaning in context.

One context at which the Court looks is, of course, the other parts of the treaty. That is, it reads the treaty, and particular articles thereof, as a whole. ${ }^{\text {is }}$ Thus, the Court in the IMCO Opinion disclosed the proper relation between two important phrases by viewing them "in the context of the whole provision" and in accord "with the structure of the Article."

Another important context to be considered is the special connotation that particular words may have had at the time they were written into the treaty. ${ }^{68}$ Thus, by examining the concept of ownership in other

\footnotetext{
${ }^{63}$ See note 9 supra and accompanying text.

os "It is a cardinal principle of interpretation that words must be interpreted in the sense which they would normally have in their context, unless such an interpretation would lead to something unreasonable or absurd." Polish Postal Service in Danzig, P.C.I.J., ser. B, No. II at 39 (1925). Quoted with approval in Competence of the General Assembly for the Admission of a State to the United Nations, [1950] I.C.J. Rep. 4, 8 (Advisory Opinion of March 3, 1950).

"Anglo-Iranian Oil Co. Case (Preliminary Objection) (United Kingdom v. Iran), [1952] I.C.J. Rep. 93, I04 (Judgment of July 22, 1952).

${ }^{60}$ Hudson observes that the "context" in which words are to be construed is not limited to a particular sentence or paragraph but may be a particular part of the instrument, the instrument as a whole, the versons of the text in different languages, or the texts of several interrelated and interdependent instruments. Hudson, supra note 57 at $646-47$.

6? [1960] I.C.J. Rep. at I60. As the Permanent Court of International Justice has said, "[I] $\mathrm{t}_{\mathrm{t}}$ obvious that the treaty must be read as a whole, and that its ineaning is not to be determined merely upon particular phrases which, if detached from the context, may be interpreted in more than one sense." Competence of the International Labour Organisation, P.C.I.J., ser. B, Nos. 2 \& 3 at 23 (1922). Accord, The Ambaticlos Case, (Merits: Obligation to Arbitrate) (Greece v. United Kingdom), [1953] I.C.J. Rep. 10, 30 (Judgment of May 19, 1953) (dissent); Case Concerning Right of Nationals of the United States of America in Morocco (France $v$ United States of America), [1952] I.C.J. Rep. 176, 209 (Judgment of August 27, 1952).

${ }^{08}$ The critical role which contemporaneous usage may play in interpretation was demonstrated in the Morocco Case, id. at 189 . There the Court had to consider a predecessor treaty which was over 150 years old in order to determine whether the existing treaty permitted United States consular officials to exercise jurisdiction over criminal as well as civil "disputes" between United States eitizens in Morocco.
} 
treaties, the Court concluded that ownership in article 28(a) means flag registration. ${ }^{60}$ Whether the Court is concerned with the natural and ordinary meaning of the words as they. appear on the printed page or with their reasonable meaning in the larger contexts of the whole treaty and contemporaneous usage, it is employing an essentially textual approach.

\section{Conclusion}

That the Court has utilized principles of interpretation which are severally characteristic of the approach of the intentionist, the teleologist, and the textualist does not mean that it has failed to develop a consistent theory of interpretation. ${ }^{70}$ The relationship which the Court has itself assigned to these principles indicates that it puts its first reliance on the textualist principle of ordinary and natural meaning and that it resorts to other principles, of whatever theoretical allegiance, only to confirm its textual analysis or to resolve an ambiguity in the text itself. As the Court declared in the IMCO Opinion: ${ }^{71}$

The words of Article $28(a)$ must be read in their natural and ordinary meaning, in the sense which they would normally have in their context. It is only if, when this is done, the words of the Article are ambiguous in any way that resort need be had to other methods of construction.

${ }^{60}$ See note 29 supra and accompanying text. The same result was reached by application of the principle of subsequent practice. See note 2.7 supra and accompanying text.

${ }_{70}$ The Institute of International Law adopted the following resolution which reflects the theory of interpretation developed by the Court:

\section{"Article I}

1. The agreenent of the parties having been embodied in the text of the treaty, it is necessary to take the natural and ordinary meaning of the terms of this text as the basis of interpretation. The terms of the provisions of the treaty should be interpreted in their context as a whole, in accordance with good faith and in the light of the principles of international law.

2. If, however, it is established that the terms used should be understood in another sense, the natural and ordinary meaning of these terms will be displaced.

\section{Article 2}

I. In the case of a dispute brought before an international tribunal it will be for the tribunal, while bearing in mind the provisions of the first article, to consider whether and to what extent there are grounds for making use of other means of interpretation.

2. Amongst the legitimate means of interpretation are the following:

(a) Recourse to preparatory work;

(b) The practice followed in the actual application of the treaty;

(c) The consideration of the objects of the treaty." INSTITUTE OF INTERNATIONAL

LAW, 46 ANNUAIRE 358-59, 364-65 (1956).

${ }^{71}$ [1960] I.C.J. Rep. at $159-60$. 